\title{
KEBERLANJUTAN PENGEMBANGAN LORONG GARDEN DALAM MEWUJUDKAN KAWASAN PERKOTAAN RAMAH LINGKUNGAN (ECO CITY) DI MAKASSAR
}

\author{
A. Wisneni' ${ }^{1}$, Abdullah ${ }^{2}$ dan Annas Boceng ${ }^{2}$ \\ 1Dinas Pengelolaan Lingkungan Hidup Provinsi Sulawesi Selatan \\ ${ }^{2}$ Program Studi Magister Agroteknologi Universitas Muslim Indonesia \\ Email : andineneng189@gmail.com, abdullahsituru@ymail.com, bocengannas@ymail.com,
}

\begin{abstract}
The Lorong Garden (aisle farming) program is one of the efforts of Makassar City Government to improve the area of narrow aisles or narrow streets in residential areas to make it more comfortable and healthier (ecological) and productive (economic). The program is expected to be able to improve the quality of the environment, community participation, and the economy of the community. The sustainability of its management is influenced by several integrated components. The study aims to analyze the sustainability of Lorong Garden development in Makassar City. Research in the form of a questionnaire interview survey of 126 respondents of the general public and 25 experts /stakeholders in the city of Makassar. Index analysis and sustainability status were using MDS methods Rap-Longgar-Potensial. The results showed that the multidimensional Lorong Garden Program is less sustainable (index 43.02\%). Partially, there were two dimensions in the moderately sustainable category namely the ecological dimension (index 51.84\%) and the technology dimension (index 65.09\%) and three dimensions less sustainable, namely economy (index 46.15\%), social (index 49.81) \%) and institutional (index $39.20 \%$ ). Of the total 37 attributes were analyzed, 17 sensitive attributes affected the sustainability of the Lorong Garden development in Makassar City.
\end{abstract}

Keyword : Sustainability; Lorong Garden; $M D S$

\section{PENDAHULUAN}

Kota Makassar merupakan kota metropolitan yang sebagian besar wilayahnya, terutama di pusat kota, tertutup oleh infrastruktur jalan dan bangunan lainnya yang berdampak terhadap kualitas lingkungan dan keseimbangan ekosistem serta kehidupan sosial ekonomi masyarakatnya (Abdullah, 2017).

Data BPS kota Makassar (2014), menunjukkan bahwa kondisi Ruang Terbuka Hijau (RTH) eksisting kota Makassar hanya 9,2\% dan setiap tahun terus mengalami penurunan. Kondisi ini masih jauh dari amanat UU No. 26 Tahun 2007, bahwa penyediaan dan pemanfaatan RTH dengan proporsi paling sedikit 30\% dari luas wilayah kota.

Salah satu cara meningkatkan kualitas

pada kondisi keterbatasan ruang dan lingkungan di kota Makassar yaitu dengan menghadirkan sebuah program inovasi yang memadukan antara fungsi ruang terbuka hijau (RTH) dalam urban agriculture (UA) pada masyarakat kota yaitu Lorong Garden (Longgar).

Lorong Garden merupakan program pemerintah kota Makassar dalam penataan lorong/gang pemukiman penduduk yang lebih nyaman (ekologi) dan produktif bagi masyarakat melalui kegiatan bertani dan diberi akronim Longgar. Keberadaan program 
ini dapat dijadikan sebagai bagian penting dari struktur pembentuk kota berkelanjutan.

Menurut Elliott (2006) landasan filosofis kota berkelanjutan adalah menghadirkan keseimbangan antara perkembangan kota, baik fisik maupun sosial ekonomi, dan daya dukung lingkungan agar terwujudnya harmonisasi kehidupan generasi pada saat ini dan masa mendatang. Sedangkan menurut Susanto (2003) pembangunan berkelanjutan harus dilakukan dengan bertumpu kepada empat pilar yaitu: (1) secara ekonomi fisibel (economically feasible), (2) penggunaan teknologi sepadan (technologically appro-priate), (3) secara lingkungan tidak merusak dan berkelanjutan (envornmentally sound and sustainnable), (4) secara sosial budaya dapat diterima (socially and culturally acceptable).

Pengembangan Lorong Garden merupakan suatu langkah yang diharapkan mampu mengatasi permasalahan kota yakni terwujudnya kehidupan kota yang ekonomis, ekologis, dan kehidupan sosial-budaya yang berkelanjutan. Selain itu, sebagai sarana edukasi bagi masyarakat untuk dapat lebih peduli akan lingkungan tempat tinggalnya. Semakin baik kualitas lingkungan tempat tinggal, maka masyarakat yang tinggal di lingkungan tersebut akan semakin bahagia karena didukung dengan lingkungan yang nyaman, indah, dan asri.

Upaya pengembangan program Lorong Garden melibatkan berbagai komponen,

elemen atau unsur di dalamnya yang saling terintegrasi dan berpengaruh terhadap keberlanjutannya. Strategi yang dapat dilakukan dalam pengembangan program Lorong Garden yaitu pendekatan berdasarkan dimensi keberlanjutan pengembangannya. Hal ini sangat penting dilakukan karena dapat memberikan informasi atau gambaran tentang aspek atau indikator yang dapat mempengaruhi upaya pengembangan potensi lorong yang ada di kota Makassar.

Penelitian ini bertujuan menganalisis nilai indeks dan status keberlanjutan pengembangan Lorong Garden di Kota Makassar.

\section{METODE PENELITIAN}

Penelitian ini dilakukan pada 14 Kecamatan di Kota Makassar, yakni setiap kecamatan dipilih berdasarkan adanya kegiatan program Lorong Garden. Pemilihan sampel responden masyarakat umum dilakukan secara acak sebanyak 126 orang dan responden pakar/stakeholders ditentukan secara sengaja (purposive) sebanyak 25 orang. Pakar/ stakeholders terdiri dari pakar sosiologi kemasyarakatan, pertanian, aparat pemerintah kota (Dinas Perikanan dan Pertanian, Dinas Lingkungan Hidup Daerah, Dinas Ketahanan Pangan, Kepala Kecamatan, Penyuluh Pertanian Lapangan (PPL) Kota Makassar), Kelompok PKK, lembaga swadaya masyarakat (LSM), dan tokoh masyarakat.

Analisis

pengembangan keberlanjutan

Lorong Garden 
menggunakan metode Multi Dimensional Scaling (MDS) disebut teknik ordinasi RapLonggar-Potensial. Metode ini modifikasi dari program RAPFISH (Rapid Appraisal for Fisheries) yang dikembangkan Fisheries Center, University of British Columbia, Kanada (Budiharsono, 2007; Sampeliling, 2012). Metode MDS merupakan analisis statistik berbasis komputer menggunakan Software RALED-SBH (Rapid Assesment Techniques for Local Economic Development Sugen Budiharsono (Tim Pengembangan Ekonomi Lokal, BAPPENAS, 2007). Teknik ordinasi MDS Rap-Longgar-Potensial dilakukan dalam beberapa tahap (Kavanag, 2001; Sampeliling et al. 2012; Abdullah et al., 2016): (1) penentuan atribut dari lima dimensi keberlanjutan mencakup 37 atribut, yakni: 8 atribut dimensi ekologi, 9 atribut dimensi ekonomi, 7 atribut dimensi sosial, 6 atribut dimensi teknologi, dan 7 atribut dimensi kelembagaan; (2) pembuatan skor penilaian atribut dalam skala ordinal. Rentang skor: 0 (nilai buruk $=$ kondisi paling tidak menguntungkan) hingga 3 (nilai baik = kondisi paling menguntungkan); (3) analisis ordinari MDS Rap-Longgar-Potensial untuk menentukan posisi tingkat keberlanjutan dari setiap dimensi dan multidimensi. Nilai indeks dan status keberlanjutan dikelompokkan: $0-$ $25 \%($ buruk $=$ tidak berkelanjutan $), 26-50 \%$ (kurang $=$ kurang berkelanjutan), $51-75 \%$ (cukup $=$ cukup berkelanjutan), dan $76-$ $100 \%$ (baik = Sangat berkelanjutan); analisis sensitivitas (Leverage Analysis) untuk menentukan atribut sensitif berpengaruh terhadap setiap dimensi keberlanjutan dan diukur melalui perubahan Root Mean Square (RMS). Semakin besar nilai perubahan RMS, maka semakin besar atau sensitif peranan atribut tersebut terhadap peningkatan indeks dan status keberlanjutan; (5) Analisis Monte Carlo untuk menduga pengaruh galat selang kepercayaan 95\% dan dibandingkan dengan nilai indeks MDS; dan (6) Analisis validitas (Goodness of fit) model Rap-LonggarPotensial berdasarkan nilai Stress (S) dan koefisien determinasi (R2 ). Model yang baik, jika nilai $\mathrm{S}<0,25$ dan R2 mendekati 1 (95 $100 \%)$.

\section{HASIL DAN PEMBAHASAN}

\section{Indeks Keberlanjutan Multidimensi}

Hasil skoring atribut dan analisis dengan metode MDS Rap-LonggarPotential terhadap 37 atribut secara multidimensi (Ekologi, Ekonomi, Sosial, Teknologi dan Kelembagaan), diperoleh nilai indeks secara multidimensi sebesar 43,02 \% dan berada pada nilai kisaran $25,01-50,00 \%$ yang berarti dalam status kurang berkelanjutan (Tabel 1). Nilai indeks dan status keberlanjutan ini menunjukkan bahwa pengembangan Lorong Garden di kota Makassar kurang berkelanjutan secara multidimensi (ekologi, ekonomi, sosial, teknologi dan 
kelembagaan). Namun demikian, secara parsial ada dua dimensi dalam kategori cukup berkelanjutan yaitu dimensi ekologi dan dimensi teknologi, sedangkan dimensi ekonomi, sosial dan kelembagaan kurang berkelanjutan.

Hal tersebut memberikan gambaran bahwa dalam rangka meningkatkan keberlanjutan pengembangan Lorong Garden masih memerlukan intervensi dari pemerintah dan stakeholders lainnya. Intervensi dilakukan terhadap atribut-atribut sensitif dari setiap dimensi keberlanjutan yang ditemukan dalam analisis Leverage. Menurut Sampeliling (2012) intervensi terhadap dimensi-dimensi keberlanjutan bertujuan untuk meningkatkan atau mempertahankan tingkat keberlanjutan pengembangannya dimasa akan datang.

Nilai indeks dan status keberlanjutan (sustainabilitas) lima dimensi (ekologi, ekonomi, sosial, teknologi dan kelembagaan) disajikan pada Tabel 1 berikut.

Tabel 1. Nilai indeks dan status keberlanjutan (sustainabilitas) lima dimensi (ekologi, ekonomi, sosial, teknologi dan kelembagaan) pengembangan Lorong Garden di kota Makassar, 2020

\begin{tabular}{ccc}
\hline Dimensi & IndeksKeberlanjutan $(\%)$ & Status Keberlanjutan \\
\hline Ekologi & 51,84 & Cukup berkelanjutan \\
Ekonomi & 46,15 & Kurang berkelanjutan \\
Sosial & 49,81 & Kurang berkelanjutan \\
Teknologi & 65,09 & Cukup berkelanjutan \\
Kelembagaan & 39,20 & Kurang berkelanjutan \\
Multidimensi & 43,02 & Kurang berkelanjutan \\
\hline
\end{tabular}

\section{Keberlanjutan Dimensi Ekologi}

Dimensi ekologi menyertakan 8 atribut untuk analisis keberlanjutan. Atributatribut kondisi di lapangan yang diperkirakan berpengaruh terhadap keberlanjutan dimensi ekologi, yaitu (1) Manfaat ekologi/ lingkungan dari pengembangan Lorong Garden, (2) Ketersediaan luas pekarangan dari setiap kavlin rumah penduduk di wilayah lorong di Kota Makassar, (3) Pemanfaatan area pekarangan rumah dalam bentuk kegiatan pertanian lorong untuk tanaman hortikultura (mis buah-buahan dan sayuran) di wilayah Kota Makassar, (4) Jenis tanaman yang umum dikembangkan di Lorong Garden, (5) Kondisi penataan tanaman pada setiap pemukiman/rumah penduduk yang ada di Kota Makassar, (6) Ketersediaan sumber air untuk mendukung pertumbuhan tanaman dalam kegiatan Lorong Garden di wilayah kota Makassar, (7) Nilai keindahan/estetika lingkungan dengan adanya Lorong Garden di wilayah Kota Makassar, (8) Lingkungan/ 
A. Wisneni : Keberlanjutan Pengembangan Lorong Garden dalam Mewujudkan Kawasan Perkotaan Ramah Lingkungan (Eco City) di Makassar

pekarangan dapat diusahakan/dilakukan

Lorong Garden.

Hasil analisis menggunakan RapLonggar-Potensial untuk dimensi ekologi dalam kondisi cukup berkelanjutan (indeks $51,84 \%)$. Hal ini menunjukkan telah membaiknya secara ekologi kondisi eksisting pengembangan Lorong Garden di kota Makassar. Artinya manajemen pengelolaan sumberdaya lahan/lingkungan untuk aktivitas pertanian lorong telah memberikan dampak yang nyata pada perbaikan fungsifungsi ekologis. Oleh karena itu kegiatan Lorong Garden sebagai salah satu bentuk pertanian perkotaan harus ditingkatkan agar bisa lebih berkelanjutan.

Namun demikian, hasil analisis leverage (Gambar 1), masih ditemukan tiga atribut sebagai faktor sensitif berpengaruh terhadap tingkat keberlanjutan secara ekologis, yaitu (1) jenis tanaman yang yang umum dikembangkan, (2) ketersediaan luas pekarangan dari setiap kavlin rumah penduduk di wilayah lorong dan (3) ketersediaan sumber air untuk mendukung pertumbuhan tanaman. Atribut sensitif tergolong masih bermasalah dalam ketersediaan dan pemanfaataanya serta tidak tertangani dengan baik. Ketiga atribut tersebut saling terkait dalam meningkatkan pengembangan Lorong Garden untuk memberikan fungsi-fungsi ekologis. Atribut sensitif ini perlu menjadi perhatian bagi pemerintah maupun stakeholders dalam menjaga ataupun melakukan tindakan perbaikan lebih lanjut.

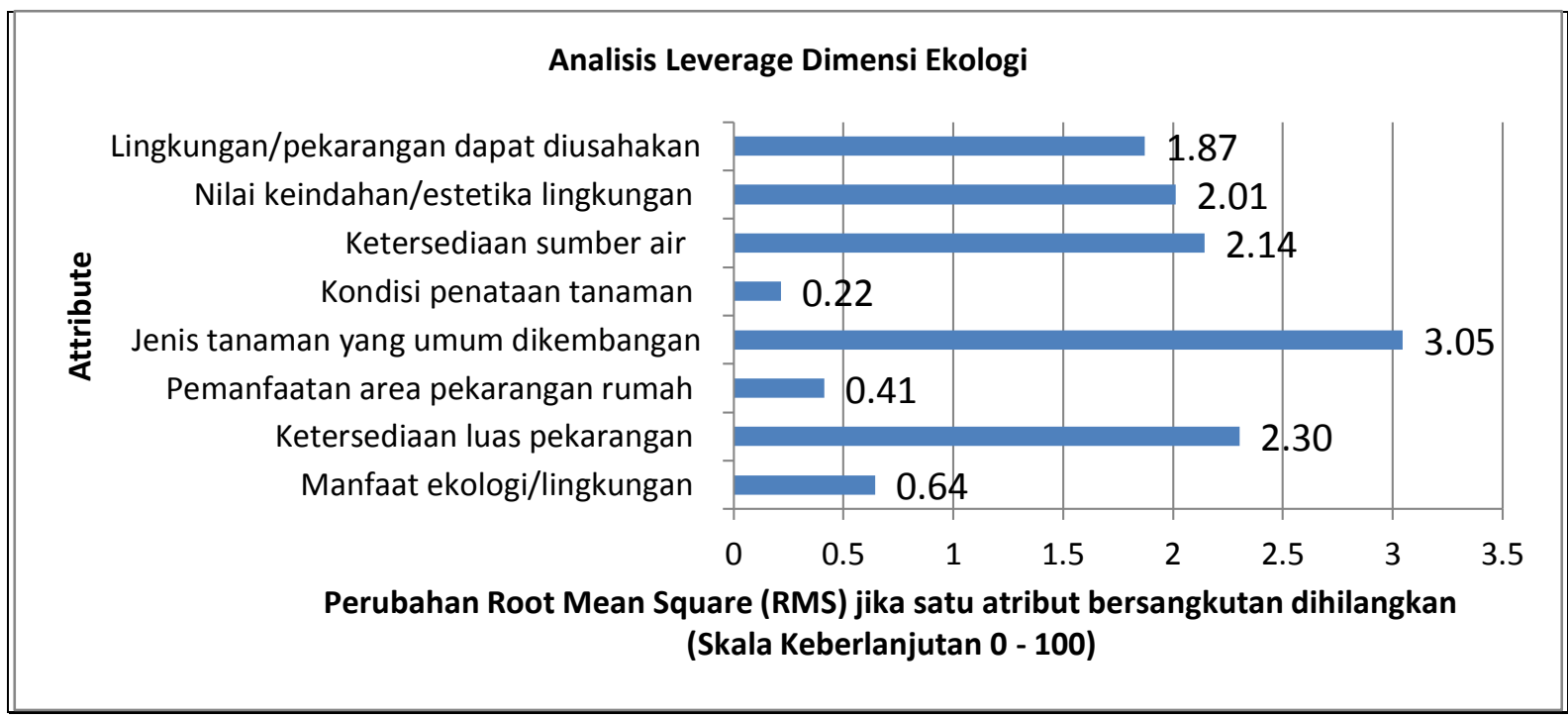

Gambar 1. Nilai sensitivitas atribut keberlanjutan dimensi ekologi pengembangan Lorong Garden di kota Makassar. 
A. Wisneni : Keberlanjutan Pengembangan Lorong Garden dalam Mewujudkan Kawasan Perkotaan Ramah Lingkungan (Eco City) di Makassar

\section{Keberlanjutan Dimensi Ekonomi}

Pada dimensi ekonomi, faktor-faktor yang diperkirakan berpengaruh terhadap status kebrlanjutanterdiri dari 9 atribut, yaitu (1) Jumlah pengeluaran/biaya yang dibutuhkan pengembangan Lorong Garden di wilayah Kota Makassar, (2) Produktivitas tanaman yang dikembangkan dalam Lorong Garden di Kota Makassar, (3) Kontribusi pengembangan Lorong Garden terhadap pendapatan rumah tangga masyarakat kota Makassar, (4) Kebutuhan modal untuk pengembangan Lorong Garden di Kota Makassar, (5) Kontribusi produk Lorong Garden untuk mensubstitusi kebutuhan atau pemenuhan pangan dan gizi keluarga di wilayah kota Makassar, (6) Tingkat kelayakan usaha tani pengembangan Lorong Garden di Kota Makassar, (7) Peran serta Badan Usaha Lorong dalam pengembangan Lorong Garden di Kota Makassar, (8) Tingkat pemasaran produk Lorong Garden yang dihasilkan di Kota Makassar, (9) Produksi kegiatan Lorong Garden dapat menghasilkan nilai tambah pada ekonomi keluarga.

Hasil analisis keberlanjutan menggunakan Rap-Longgar-Potensial untuk dimensi ekonomi diperoleh nilai indeks keberlanjutan sebesar 46,15 \% Nilai indeks ini berada pada kisaran nilai 25,01-50,00\% yang berarti bahwa status kurang berkelanjutan. Hal ini menunjukkan bahwa pengembangan Lorong Garden di kota Makassar secara ekonomis kurang dapat berjalan dalam jangka panjang.

Dari aspek dimensi ekonomi, belum cukup memberikan dampak menguntungkan kepada masyarakat, misalnya untuk perbaikan ketahanan pangan/gizi dan peningkatan pendapatan masyarakat miskin perkotaan. Namun demikian, menurut abdullah et al (2017) pertanian perkotaan dapat memberikan dampak terhadap perekonomian masyarakat. Adapun hasil analisis dari Leverage dimensi ini ditemukan empat atribut sebagai faktor sensitif berpengaruh terhadap tingkat keberlanjutan dimensi ekonomi, yaitu (1) peran serta badan usaha lorong, (2) kebutuhan modal, (3) tingkat kelayakan usaha tani, dan (4) kontribusi produk Lorong Garden untuk mensubstitusi kebutuhan atau pemenuhan pangan dan gizi keluarga (Gambar 2). Atribut-atribut sensitif tersebut perlu mendapat perhatian dan dikelola dengan baik sehingga keberlanjutan dimensi ekonomi dalam pengembangan Lorong Garden di kota Makassar dapat ditingkatkan. Hal ini berarti bahwa dalam merumuskan kebijakan upaya meningkatkan status keberlanjutan dari dimensi ekonomi perlu memperhatikan dan mempertimbangkan keempat atribut tersebut. 
A. Wisneni : Keberlanjutan Pengembangan Lorong Garden dalam Mewujudkan Kawasan Perkotaan Ramah Lingkungan (Eco City) di Makassar

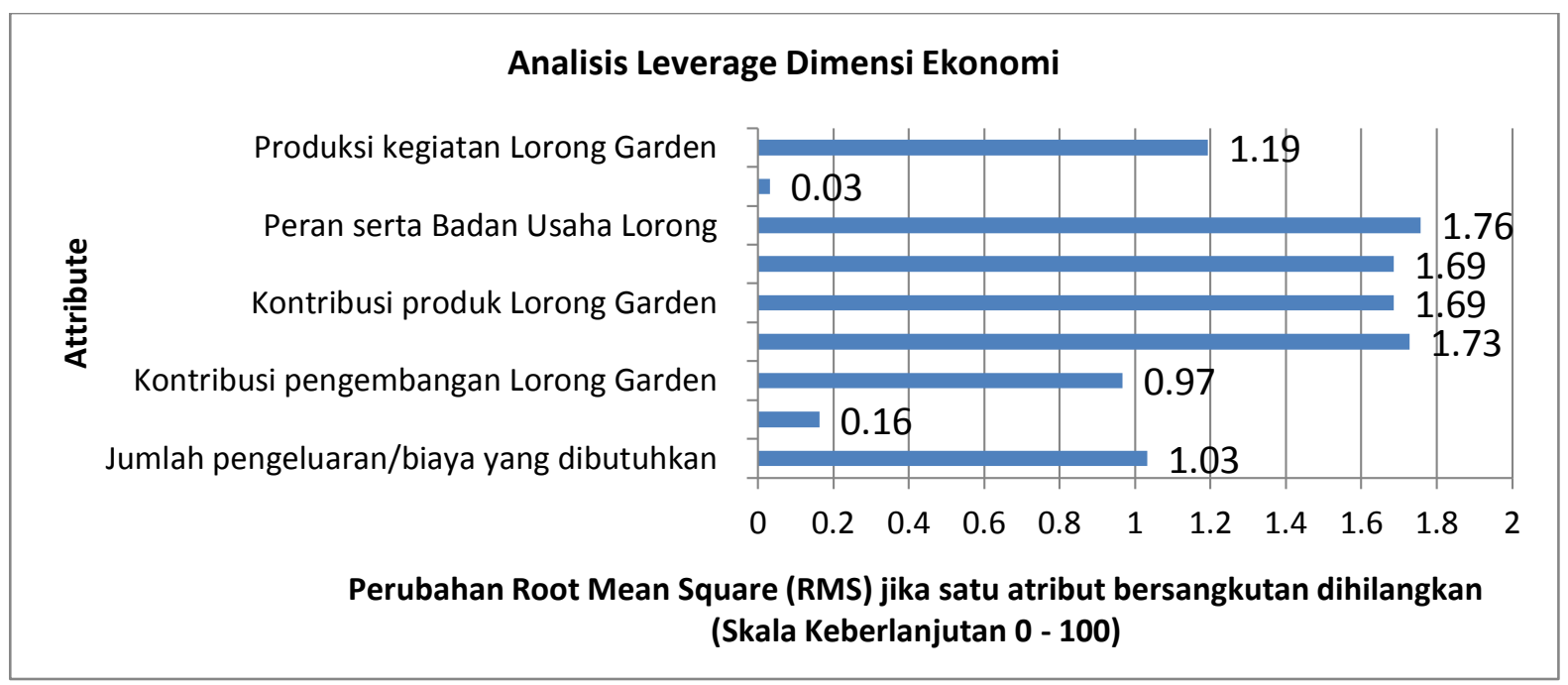

Gambar 2. Nilai sensitivitas atribut keberlanjutan dimensi ekonomi pengembangan Lorong Garden di kota Makassar

\section{Keberlanjutan Dimensi Sosial}

Faktor-faktor yang diperkirakan berpengaruh terhadap keberlanjutan dimensi sosial terdiri dari 7 atribut, yaitu (1) Pemahaman/pengetahuan masyarakat kota Makassar tentang pertanian Lorong Garden, (2) Kegiatan pertanian Lorong Garden di Kota Makassar dapat meningkatkan kekeluargaan sesama warga lorong, (3) Persepsi atau pandangan masyarakat kota Makassar dalam upaya terlibat langsung dalam pengembangan Lorong Garden, (4) Tingkat motivasi atau keinginan masyarakat kota Makassar dalam upaya terlibat langsung dalam pengembangan Lorong Garden, (5) Dukungan masyarakat kota Makassar terhadap kebijakan pengembangan Lorong Garden, (6) Pembinaan kepada masyarakat tentang kegiatan Lorong Garden, Keterlibatan kaum ibu/remaja dalam kegiatan pengembangan Lorong Garden. Hasil analisis keberlanjutan dengan Rap-LonggarPotensial untuk diemnsi sosial termasuk dalam kategori kurang berkelanjutan (indeks 49,81 \%). Hal ini menunjukkan bahwa keberadaan program Lorong Garden di kota Makassar belum dapat diterima dengan baik secara sosial oleh masyarakat.

Hasil analisis leverage (Gambar 3), terdapat empat faktor-faktor sensitif yang berpengaruh, yaitu (1) kegiatan pertanian Lorong Garden di Kota Makassar dapat meningkatkan kekeluargaan sesama warga lorong, (2) pembinaan kepada masyarakat tentang kegiatan Lorong Garden, (3) pemahaman atau pengetahuan masyarakat kota Makassar tentang pertanian Lorong Garden dan (4) keterlibatan kaum ibu/remaja dalam kegiatan pengembangan Lorong Garden. Hal ini berarti dalam upaya meningkatkan status 
A. Wisneni : Keberlanjutan Pengembangan Lorong Garden dalam Mewujudkan Kawasan Perkotaan Ramah Lingkungan (Eco City) di Makassar

keberlanjutan dari dimensi sosial, keempat atribut ini memerlukan perhatian dan pertimbangan yang lebih khusus. Selain peran masyarakat masih sangat minim karena umumnya mereka tidak mengetahui apa yang harus dilakukan, sehingga perlu pembinaan dan dorongan yang kuat dari pemerintah. Motivasi dan dukungan masyarakat sesungguhnya sangat baik, hal ini terlihat dalam penelitian Abdullah et al (2017) menunjukkan 64,34\% memiliki motivasi dalam pengembangan pertanian perkotaan.

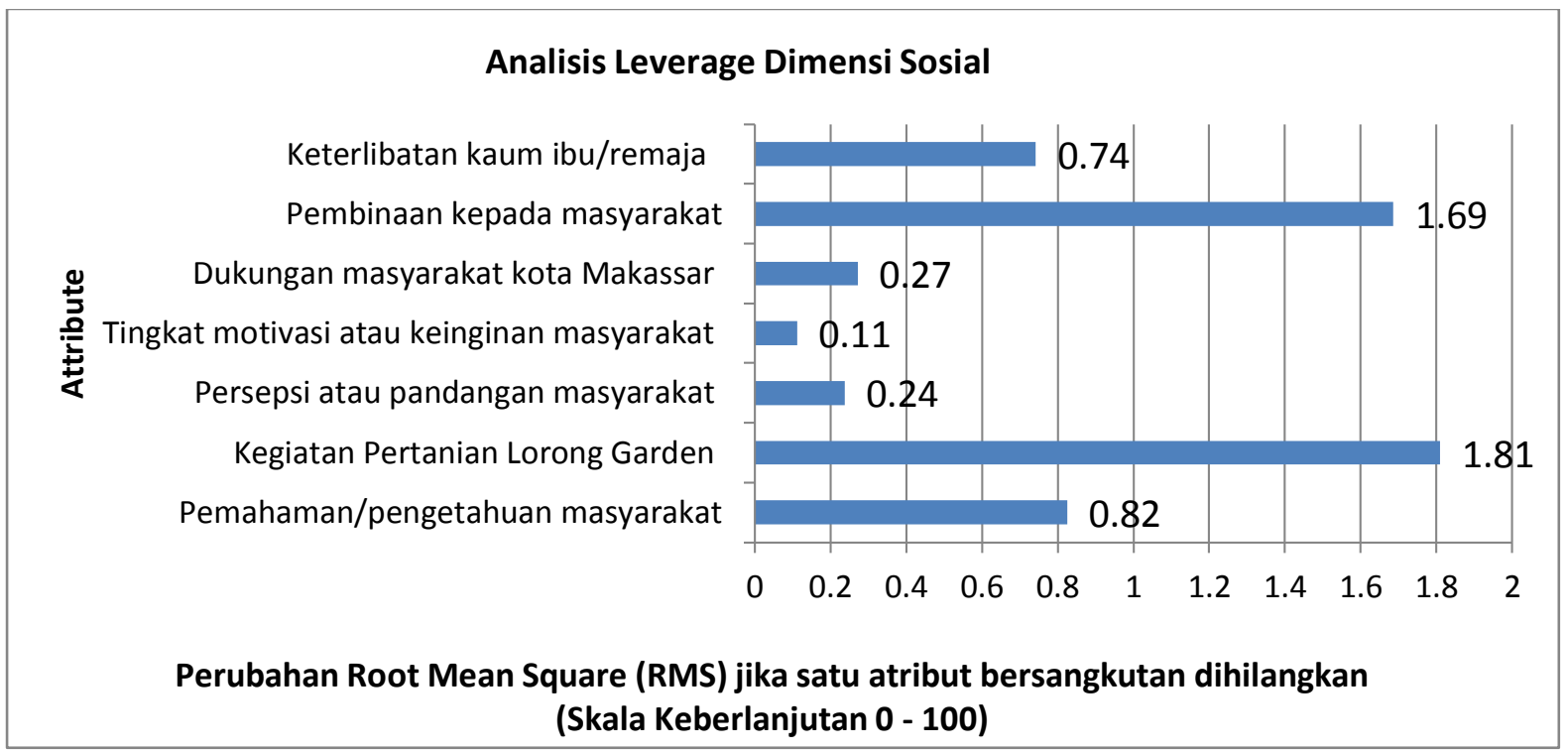

Gambar 3. Nilai sensitivitas atribut keberlanjutan dimensi sosial pengembangan Lorong Garden di kota Makassar.

\section{Keberlanjutan Dimensi Teknologi}

Faktor-faktor yang diperkirakan berpengaruh terhadap keberlanjutan dimensi teknologi terdiri dari 6 atribut, yaitu (1) Pengelolaan Lorong Garden yang dilakukan masyarakat, (2) Ketersediaan teknologi budidaya tanaman (system pot/polybag, vertikultur, hidroponik, dll) untuk Lorong Garden, (3) Pemahaman masyarakat kota Makassar terhadap penerapan teknologi budidaya tanaman dalam kegiatan pengembangan Lorong Garden, (4) Tingkat penerapan teknologi budidaya tanaman dalam pengembangan Lorong Garden, (5) Ketersediaan sumber informasi teknologi yang dapat diakses masyarakat, (6) Tingkat kemampuan/keterampilan masyarakat dalam pengembangan pertanian Lorong Garden.

Hasil analisis ordinasi MDS RapLonggar-Potential terhadap 6 atribut dimensi teknologi diperoleh nilai indeks keberlanjutan sebesar 65,09\% yang berarti status cukup berkelanjutan. Hal ini menunjukkan bahwa pengembangan Lorong 
A. Wisneni : Keberlanjutan Pengembangan Lorong Garden dalam Mewujudkan Kawasan Perkotaan Ramah Lingkungan (Eco City) di Makassar

Garden di kota Makassar telah mendapatkan dukungan inovasi teknologi seperti pot/polybag, vertikultur, hidroponik dan polybag serta teknologi rambatan pada areaarea terbangun (teras dan atap rumah) dan lorong-lorong perumahan yang dapat diterapkan oleh masyarakat sesuai dengan kondisi lingkungannya. Ketersediaan sarana teknologi yang tepat sangat penting artinya karena berkaitan langsung dengan aspek produktivitas tanaman dan efektivitas pemanfaatan sumber daya lahan/ruang lorong serta dapat diterapkan oleh masyarakat akan mendukung keberlanjutan pengembangannya.
Hasil analisis dari leverage menunjukkan bahwa faktor yang berpengaruh sensitif terhadap keberlanjutan dimensi teknologi terdapat tiga atribut (Gambar 4) yaitu (1) tingkat penerapan teknologi budidaya tanaman dalam kegiatan pengembangan Lorong Garden, (2) pemahaman masyarakat kota Makassar terhadap penerapan teknologi budidaya tanaman dalam kegiatan pengembangan Lorong Garden dan (3) ketersediaan sumber informasi teknologi yang dapat diakses masyarakat. Atribut sensitif ini akan berpengaruh secara signifikan dalam mempertahankan status keberlanjutan dimensi teknologi.

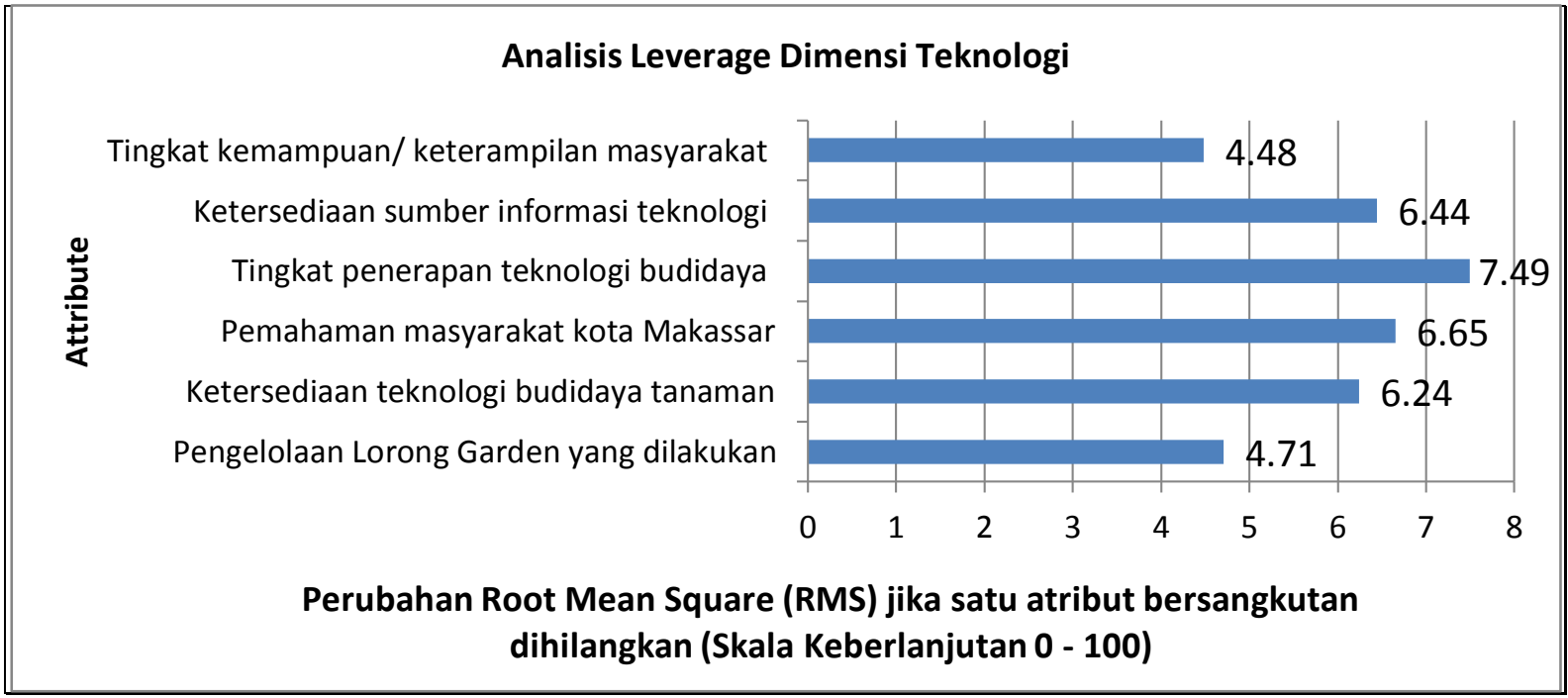

Gambar 4. Nilai sensitivitas atribut keberlanjutan dimensi teknologi pengembangan Lorong Garden di kota Makassar.

Perkembangan informasi teknologi memanfaatkan sampah organik kota, sangat penting dalam pengelolaan Lorong penggunaan pupuk organik sebagai upaya Garden, terutama kaitannya dengan pengembangan pertanian sehat dan aman. teknologi ramah lingkungan, seperti Menurut Adiyoga (2003) dan Widyawati 
A. Wisneni : Keberlanjutan Pengembangan Lorong Garden dalam Mewujudkan Kawasan Perkotaan Ramah Lingkungan (Eco City) di Makassar

(2013) mengacu pada kondisi spesifik wilayah perkotaan (urban), pengembangan atau perancangan model sistem pertanian perkotaan harus memperhatikan dua kriteria, yaitu hemat lahan dan produk bersih serta aman. Pemanfaatan lahan pekarangan/ lorong secara efisien dan efektif dapat diintervensi dengan penerapan teknologi ramah lingkungan dan pemilihan jenis tanaman sesuai kebutuhan masyarakat.

\section{Keberlanjutan Dimensi Kelembagaan}

Faktor-faktor yang diperkirakan berpengaruh terhadap keberlanjutan dimensi kelembagaan terdiri dari 7 atribut yaitu (1) Ketersediaan dukungan pemerintah melalui perda atau instruksi Walikota/Gubernur terhadap pengembangan dan keberlanjutan Lorong Garden, (2) Ketersediaan lembaga pendanaan untuk pengembangan Lorong Garden, (3) Keberadaan dan keterlibatan LSM/Organisasi lainnya dalam upaya mendukung pengembangan Lorong Garden, (4) Ketersediaan dan efektifitas kelembagaan penyuluhan pertanian dalam pengembangan Lorong Garden, (5) Ketersediaan sarana pelatihan dan penyuluhan untuk upaya pengembangan Lorong Garden, (6) Peran dan efektifitas instansi terkait dalam mendukung program dan implementasi kebijakan terkait Lorong Garden dan (7)
Dukungan RT/RW untuk pengembangan Lorong Garden.

Hasil analisis ordinasi MDS RapLonggar-Potential terhadap 7 atribut dimensi kelembagaan diperoleh nilai indeks keberlanjutan sebesar 39,20\%, Nilai indeks berada pada kisaran nilai 25,01 - 50,00\% yang berarti bahwa status kurang berkelanjutan. Artinya keberadaan program Lorong Garden di kota Makassar masih kurang mendapat dukungan secara kelembagaan baik dari pemerintah kota maupun stakeholder lainnya. Oleh karena itu agar keberlanjutan program Lorong Garden pada dimensi kelembagaan meningkat maka keberadaan dari lembaga tersebut perlu diperhatikan dengan baik dan lebih dioptimalkan lagi kinerjanya.

Hasil analisis leverage terdapat tiga atribut sensitif pada dimensi kelembagaan (Gambar 5) yaitu ketersediaan lembaga pendanaan untuk pengembangan Lorong Garden peran dan efektifitas kelembagaan penyuluhan pertanian dan dukungan $\mathrm{RT} / \mathrm{RW}$ untuk pengembangan Lorong Garden. Atribut sensitif ini akan berpengaruh secara signifikan dalam meningkatkan status keberlanjutan dimensi kelembagaan dimana yang akan datang, sehingga atribut-atribut tersebut perlu mendapat perhatian dan dikelola dengan baik. 
A. Wisneni : Keberlanjutan Pengembangan Lorong Garden dalam Mewujudkan Kawasan Perkotaan Ramah Lingkungan (Eco City) di Makassar

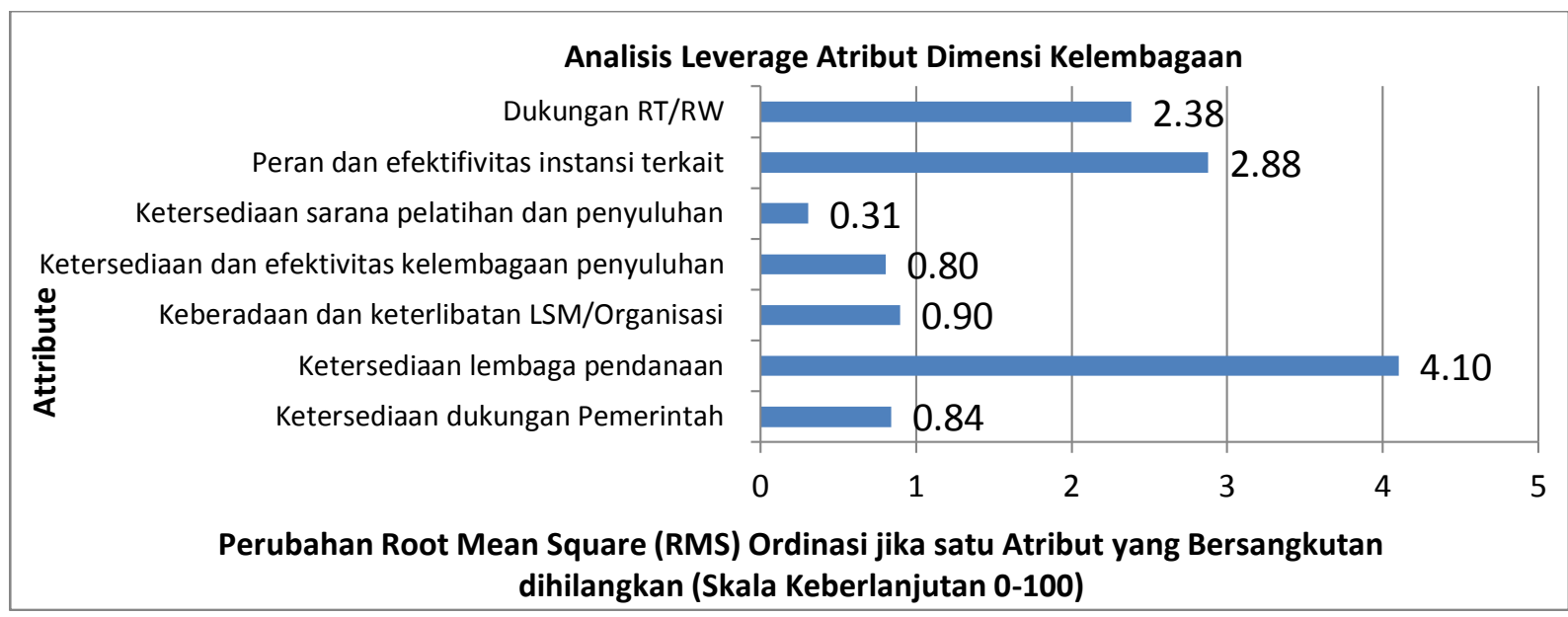

Gambar 5. Nilai sensitifitas atribut keberlanjutan dimensi kelembagaan pengembangan Lorong Garden di kota Makassar.

\section{Uji Validitas dan Ketepatan Model Analisis}

Untuk menguji tingkat kepercayaan nilai indeks maupun dimensi digunakan analis Monte Carlo. Hasil analsis Monte Carlo digunakan sebagai pembanding terhadap hasil analisis Rap-LonggarPotential dengan tujuan melihat pengaruh kesalahan acak atau galat (random error) dalam pembuatan setiap atribut maupun kesalahan prosedur analisis statistik terhadap dimensi ekologi, ekonomi, sosial, teknologi dan kelembagaan, sehingga mempunyai tingkat kepastian dan kepercayaan yang tinggi.

Hasil analisis Monte Carlo untuk masing-masing dimensi pada taraf kepercayaan $95 \%$ menunjukkan bahwa selisih antara hasil analisis MDS Rap-
Longgar-Potential dan Monte Carlo tidak mengalami perbedaan yang signifikan (selisihnya relatife kecil) sebagaimana ditunjukkan pada Tabel 2. Keadaan tersebut menjelaskan bahwa simulasi menggunakan MDS Rap-Longgar-Potential memiliki tingkat kepercayaan tinggi (Kavanagh dan Pitcther, 2004). Kecilnya perbedaan nilai indeks keberlanjutan antara hasil analisis metode MDS Rap-Longgar-Potential dengan Monte Carlo mengindikasikan bahwa : (1) kesalahan dalam membuat skor setiap atribut relatife kecil, (2) variasi pemberian skor akibat perbedaan opini relatif kecil, (3) proses analisis yang dilakukan secara berulang-ulang stabil, (4) kesalahan memasukkan data yang hilang dapat dihindari (Thamrin, et al, 2007 
A. Wisneni : Keberlanjutan Pengembangan Lorong Garden dalam Mewujudkan Kawasan Perkotaan Ramah Lingkungan (Eco City) di Makassar

Tabel 2. Perbedaan nilai indeks keberlanjutan dan Monte Carlo pada selang kepercayaan 95\%

DimensiKeberlanjutan

\begin{tabular}{lccc}
\cline { 2 - 3 } & MDS & Monte Carlo & Perbedaan \\
\hline Ekologi & 51,84 & 51,80 & 0,04 \\
Ekonomi & 46,15 & 45,66 & 0,49 \\
Sosial & 49,81 & 49,48 & 0,33 \\
Teknologi & 65,09 & 62,72 & 2,37 \\
Kelembagaan & 39,20 & 39,85 & 0,65 \\
Multidimensi & 43,02 & 42,95 & 0,07 \\
\hline
\end{tabular}

Sumber : Hasil Analisis, 2020

Pada Tabel 2 terlihat perbedaan hasil analisis relatif kecil, hal ini menunjukkan bahwa analisis Rap-Longgar-Potential dengan menggunakan metode MDS untuk menetukan keberlanjutan pengembangan Lorong Garden di kota Makassar memiliki tingkat kepercayaan yang tinggi dan cukup baik digunakan sebagai salah satu alat evaluasi untuk pengembangan Lorong Garden di kota Makassar.

Menurut Hidayanto,et al (2009), untuk mengetahui perlu tidaknya penambahan atribut dan mencerminkan keakurat dimensi yang dengan keadaan sebenarnya dilakukan analisis nilai Stress (S) dan koefisien determinasi $\left(\mathrm{R}^{2}\right)$ Goodness of fit dalam MDS dicerminkan dari besaran nilai $S^{\prime}$ Stress yang dihitung berdasarkan nilai $\mathrm{S}$ dan $\mathrm{R}^{2}$, nilai S-Stress yang rendah dikaji secara akurat (mendekati kondisi menunjukkan goodfit, sedangkan nilai $S$ - sebenarnya).

Tabel 3. Hasil Analisis MDS Rap-Longgar-Potential untuk Nilai Stress dan Koefisien Determinasi

\begin{tabular}{ccccccc}
\multicolumn{6}{l}{ Tabel 3. Hasil Analisis MDS Rap-Longgar-Potential untuk Nilai Stress dan Koefisien Determinasi } \\
\hline Parameter & Multi Dimensi & $\begin{array}{c}\text { Dimensi } \\
\text { Ekologi }\end{array}$ & $\begin{array}{c}\text { Dimensi } \\
\text { Ekonomi }\end{array}$ & $\begin{array}{c}\text { Dimensi } \\
\text { Sosial }\end{array}$ & $\begin{array}{c}\text { Dimensi } \\
\text { Teknologi }\end{array}$ & $\begin{array}{c}\text { Dimensi } \\
\text { Kelembagaan }\end{array}$ \\
\hline Stress & 0,13 & 0,16 & 0,15 & 0,17 & 0,14 & 0,15 \\
R $^{2}$ & 0,96 & 0,93 & 0,93 & 0,94 & 0,95 & 0,95 \\
\hline Sumber $:$ Hasil & & & & &
\end{tabular}

Sumber : Hasil analisis, 2020

Stress yang tinggi menunjukkan sebaliknya (Fauzi dan Anna, 2005). Menurut Kavanagh dan Pitcter (2004), model cukup baik jika nilai $S$-Stress lebih kecil dari $0.25(\mathrm{~S}<0,25)$, dan $\mathrm{R}^{2}$ yang baik mendekati 1 (100\%), artinya bahwa atribut-atribut yang terpilih saat ini dapat menjelaskan mendekati $100 \%$ dan model yang lain.

Adapun parameter statistik dari analisis MDS Rap-Longgar-Potential berfungsi sebagai standar untuk menentukan kelayakan terhadap hasil kajian yang dilakukan di wilayah penelitian ( Tabel 3). Menunjukkan nilai “stress" dan $\mathrm{R}^{2}$ (koefisien determinasi) untuk setiap dimensi maupun multi dimensi. Nilai tersebut berfungsi untuk menentukan perlu tidaknya penambahan atribut untuk mencerminkan dimensi yang

fit delress yang dihitung berdasarkan nilai 
Berdasarkan Tabel 3 pada masing-masing dimensi maupun multidimensi memiliki nilai "stress" yang jauh lebih kecil dari ketetapan yang menyatakan bahwa nilai "stress" pada analisis dengan metode MDS sudah baik jika diperoleh nilai lebih kecil dari 0,25 atau $25 \%$ (Kavanagh dan Pitcther, 2004), karena semakin kecil nilai "stress" yang diperoleh berarti semakin baik kualitas hasil analisis yang dilakukan. Berbeda dengan nilai koefisien determinasi $\left(\mathrm{R}^{2}\right)$, kualitas hasil analisis semakin baik jika nilai koefisien determinasi $\left(\mathrm{R}^{2}\right)$ semakin besar (mendekati 1). Dengan demikian dari kedua parameter (nilai "stress"dan $\mathrm{R}^{2}$ ) menunjukkan bahwa seluruh atribut yang digunakan pada analisis keberlanjutan pengembangan Lorong Garden di kota Makassar sudah cukup baik dalam menerangkan lima dimensi yang dianalisis.

\section{KESIMPULAN DAN SARAN}

\section{Kesimpulan}

Pengembangan Lorong Garden di kota Makassar secara multidimensi (ekologi, ekonomi, sosial, teknologi, dan kelembagaan) kondisi existing dalam status kurang berkelanjutan (indeks 43,02 \% \%). Secara parsial terdapat dua dimensi status cukup berkelanjutan, yakni dimensi ekologi (indeks 51,84\%) dan teknologi (indeks 65,09 $\% \%)$, tiga dimensi kurang berkelanjutan, yakni dimensi ekonomi (indeks 46,15\%), dimensi sosial (indeks 49,81\%) dan dimensi kelembagaan (indeks 39,20\%)

\section{Saran}

Untuk meningkatkan keberlanjutan pengembangan Lorong Garden perlu dilakukan intervensi dan perbaikan oleh pemerintah kota Makassar dan stakeholder dalam meningkatkan kinerja atribut sensitif yang berpengaruh, terutama pada dimensi yang kurang berkelanjutan (ekonomi, sosial dan kelembagaan).

\section{DAFTAR PUSTAKA}

Abdullah. 2016. Tingkat Keberlanjutan dan Model Perilaku Berwawasan Lingkungan Masyarakat dalam Pengembangan Sistem Pertanian Perkotaan (Urban Farming ) di Kota. Laporan Hibah Doktor, Kerjasama LPM UMI dan Direktorat Riset dan Pengabdian Masyarakat-Kemenristek dikti, Tahun Anggran 2015/2016 (Tidak dipublikasikan).

Abdullah; N.Pertiwi; F. Amin; S.Sapareng. 2017. Citizen Behavior Model in Urban Farming Development. 2nd International Conference on Education, Science and Technology (ICEST 2017). Advance in Social Science, Education and Humaties Research (ASSEHR). Vol.149:16-18. Atlantis Press.

Abdullah; G.D.Dirawan; N.Pertiwi.2017. Sustainability of ecology and economic of urban farming development : Case Study In Makassar City, South Sulawesi Province.Eco.Env.\&Cons. 23(1) : 125130

Abdullah; A. Haris; A. Boceng; 2019. Persepsi dan Pola Perilaku Masyarakat 
dalam Pengembangan Pertanian

Perkotaan sebagai Upaya Memperkuat

Sistem Ketahanan Pangan Keluarga :

Studi Kasus Kota Makassar Sulawesi

Selatan. Seminar Nasional Dalam

Rangka Dies Natalis UNS ke 43.

Adiyoga, W. 2003. Prospek pengembangan

pertanian urban (perkotaan). Makalah disampaikan pada Diseminasi Prospek Pengembangan Sayuran di Perkotaan, Balai Penelitian Tanaman Sayuran, Lembang, Bandung, 11-13 Agustus 2003.

Budiharsono, Sugeng. (2007). Teknik Analisa Pembangunan dan Pesisir. Jakarta: Pradnya Paramita.

[BPS] Badan Pusat Statistik (BPS) Kota Makassar. 2014. Makassar Dalam Angka 2014. Biro Pusat Statistik Provinsi Sulawesi Selatan.

Elliott, J.A. 2006. An Introduction to Sustain-able Development. 3rded.

Routledge. Taylor \& Francis Group. London.

Hidayanto, M., Supriadi, S., Yahya, S., dan Amien L.I. 2009.Analisis Keberlanjutan Perkebunan Kakao Rakyat di Kawasan Perbatasan Pulau Sebatik, Kabupaten Nunukan. Provinsi Kalimantan Timur. Jurnal Agro Ekonomi, 27 (2),
213- 229.

Kavanagh, P. and T Pitcher. 2004. Implementing Microsoft Exel Software For Rapfish:A Technique For The Rappid Appraisal Of Fisheries Status.Universityof British Colombia. Canada. Fisheries Centre Research Repost.

Sampeliling, S., Santun R.P. Sitorus, Siti Nurisyah, dan Bambang Pramudya. 2012. Kebijakan Pengembangan Pertanian Kota Berkelanjutan: studi kasus di DKI Jakarta. Jurnal Analisis Kebijakan. Vol. 10 No.3. September 2012: $257-267$.

Susanto, S. 2003. Agroekologi sebagai basis dalam pembangunan pertanian berkelanjutan. Revitalisasi Pertanian dan Dialog Peradaban. Kompas Press. Hal.:415 - 427.

Thamrin, M., Sutjahjo, S.H., Haerison, S., dan Sabiham, S. 2007. Analisis Keberlanjutan Wilayah Perbatasan Kalimantan Barat - Malaysia untuk Pengembangan Kawasan Agropolitan. Jurnal Agro Ekonomi, 25 (2), 103 - 124.

Widyawati, N. 2013. Urban Farming: Gaya bertani spesifik kota. Yogyakarta: Lily Publisher. 